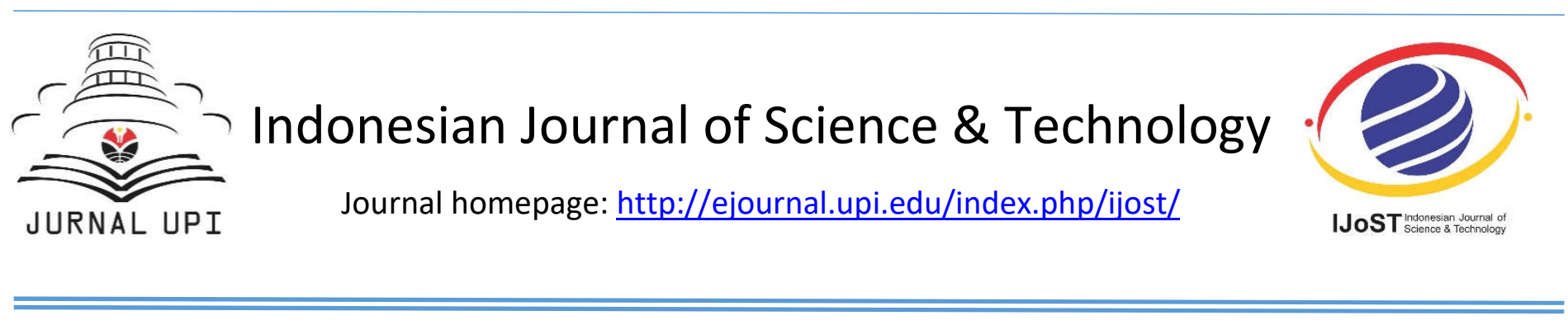

\title{
Kinetic and Thermodynamics Studies on the Adsorption of Phenol on Activated Carbon from Rice Husk Activated by $\mathrm{ZnCl}_{2}$
}

Andi Muhammad Anshar, Paulina Taba, and Indah Raya*

Faculty of Mathematics and Natural Science, Universitas Hasanuddin, Makassar 90254, Indonesia

*Corresponding author: Email: indahraya05@gmail.com

\begin{abstract}
A B S T R A C T
The purpose of this study was to investigate the adsorption ability of activated carbon from rice husk in adsorbing phenol. Activated carbon used was in this studies burning risk husk at 300 and $400^{\circ} \mathrm{C}$ and then activated by $10 \%$ of $\mathrm{ZnCl}_{2}$. The from activated carbon was characterized using an Infrared Spectrometer, an X-ray diffraction, an Scanning Electron Microscope, and a gas sorption analyzer. The best activated carbon for adsorbing phenol was the activated carbon that prodused from the burning of rice husk at a temperature $400^{\circ} \mathrm{C}$ and activated with $10 \%$ of $\mathrm{ZnCl}_{2}$ for 24 hours. Adsorption capacity of the best activated carbon was $3.9370 \mathrm{mg} / \mathrm{g}$ adsorbent with Gibbs free energy of -25.493 $\mathrm{kJ} / \mathrm{mol}$

(C) 2016 Tim Pengembang Journal UPI
\end{abstract}

\author{
ARTICLE INFO \\ Article History: \\ Submitted/Received 2 Jan 2016 \\ First Revised 18 Feb 2016 \\ Accepted 23 Feb 2016 \\ First Available online 29 Mar 2016 \\ Publication Date 01 Apr 2016 \\ Keywords: \\ Carbon \\ Rice husk \\ $\mathrm{ZnCl}{ }_{2}$ \\ Adsorption phenol
}




\section{INTRODUCTION}

The development in the industrial sector as well as science and technology gives beneficial effects for not only human but also surrounding environment. This can be found in the increases in the number and the types of pollutants from the industrial sector and then into the environment, especially the marine environment (Anshar, 2006).

Water pollution is a major problem. Various kinds of pollutants, both derived from metals such as chromium (Wahjuni et al., 2005), lead, cadmium, copper, zinc and nickel (Tarigan et al., 2003) as well as derived from organic compounds commonly found as contaminants in the environment waters (Elias et al., 2001). One of the harmful organic pollutants is phenol and its derivatives. Phenol can cause skin irritation, degradation of proteins, and paralysis of the central system nervous (Qadeera et al., 2002). Phenol is a compound that is highly soluble in water so that the presence of chlorine in the water will cause the formation of chlorophenol as 2chlorophenol (o-chlorophenol or 2-hydroxy chlorobenzene) naturally. Phenolic compounds are harmful to the organism despite low concentration of phenolic compounds and many of these are classified as a dangerous pollutant because it has the possibility of adverse human health (Kermani et al., 2006).

Phenolic compounds whose presence in aquatic environments exceeding the threshold can cause environmental pollution. Phenolic compounds undergo a transformation in the nature of chemistry, biochemistry and physics but the natural process is not sufficient to eliminate the existence of this waste. Phenol and derivatives including 2-chlorophenol need to be eliminated or reduced to the threshold limit value (Edwin, 2005). Various methods have been used to reduce the presence of phenol and its derivatives, such as by using fly ash coal (Estevinho et al., 2007), hydrotalcite (Yapar et al., 2004), clays (Mortland et al., 1986), photo degradation (Elias et al., 2001), the bacteria for aerobic biodegradation (Anwar et al., 2016), crosslinked chitosan composite membrane, (Rahmi 2007) and activated carbon from walnut shells (Estevinho et al., 2006).

A common technique used in removing or reducing the concentration of organic pollutants in aquatic environments is using activated charcoal, or known as activated carbon (Sembodo, 2005). Activated carbon has a good adsorption capability. Activated carbon adsorption capacity depens on a surface area of the carbon, high adsorption capacity, and retention of relatively rapid kinetics (Edwin, 2005).

Many methods have been suggested to get activated carbon.(Rahman et al., 2015). To make activated carbon to be more economical, practical, and efficient, the researchers use agricultural waste such as coconut shell (Rahmi, 2007), shell hazelnut (Edwin, 2005), walnut shells (Estevinho et al., 2006), Amapas cane (Kalderis et al., 2008) and rice husk (Watari et al., 2005).

Every active carbon, has unique characteristics that influence by the source of active carbon and their process to made. The activation process for activating charcoal or carbon material is to expand the surface of activated carbon to activated carbon absorption capacity will be increased. Carbon activation method can be grouped into 2 of the activation methods of chemical and physical activation method. Carbon activation method by chemically is done by adding a solution of $\mathrm{ZnCl}_{2}$ (Abdullah et al., 2001) and $\mathrm{KOH}$ (UbagoPerez et al., 2006). The purpose of the addition of the activator solution is to clean the activated carbon adsorption of 
impurities so that capacity can be increased (Danarto \& Samun, 2008).

In this study, rice husk was taken from the rice husk rice mills in Maros the district of South Sulawesi. This carbon was used for adsorbing phenol. Activated carbon is activated by $\mathrm{ZnCl}_{2} 10 \%$ by the method of soaking for 24 hours or by the method of immersion for 1 hour by heating at a temperature of $100^{\circ} \mathrm{C}$

The purpose of this study is to: (1) Determine the optimum condition of activated carbon to adsorb a phenol compound. (2) Determine the adsorption capacity of a phenol compound adsorbent (3)The functional groups that involved in the interaction between the active carbon with phenol. To understand the adsorption of our activated carbon, we compared the carbon before and after being activated by $\mathrm{ZnU}_{2}$.

\section{MATERIALS AND METHODS}

\subsection{Synthesis}

Rice husk was washed and dried in oven at $110^{\circ} \mathrm{C}$, and than heated in a furnace at $300^{\circ} \mathrm{C}$ and $400^{\circ} \mathrm{C}$ for 2 hours. After 2 hours on the furnace, active carbon was removed and cooled. After that, the activated carbon crushed and sieved. The particle size of activated carbon was 50-100 mesh. Activated carbon that has been sifted was divided into 3 sections or groups for each of the combustion temperature. The first group was active carbon that products from combustion at temperatures $300^{\circ} \mathrm{C}$ and $400^{\circ} \mathrm{C}$ and wasn't activated using a solution of $\mathrm{ZnCl}_{2} 10 \%$, the second group was carbon that products from combustion at temperatures $300^{\circ} \mathrm{C}$ and $400^{\circ} \mathrm{C}$ and activated using $10 \% \quad \mathrm{ZnCl}_{2}$ solution by immersing the activated carbon in the activator solution for 24 hours without heating (activation method 1) and the third group was carbon that products from combustion at temperatures $300{ }^{\circ} \mathrm{C}$ and 400
${ }^{\circ} \mathrm{C}$ and than activated using $10 \% \quad \mathrm{ZnCl}_{2}$ solution by immersing the activated carbon in a solution for 1 hour with heating at a temperature of $100^{\circ} \mathrm{C}$ (activation method 2 ).

\subsection{Characterization of active carbon}

Secound characterization were conducted. A faver transform infra red (FTIR), pore analyis, a scanning electron microscope(SEM), and X-Ray difraction (XRD) analysis.

Determination for optimum conditions from phenol adsorption was done dy determine the optimum time interaction, the optimum $\mathrm{pH}$, the concentration and temperature variations of phenol.

\subsection{Effect of processing time, $\mathrm{pH}$, temperature and concentration on phenolic adsorption}

Time from 1 until 240 minute were done by activated carbon rice husk as much as $1 \mathrm{~g}$ was contacted with initial concentration solution of phenol $50 \mathrm{~mL}, 50$ ppm and then filtered, the concentration of phenolic in the filtrate was analyzed by UVVis spectrophotometer. Adsorption with variation of $\mathrm{pH}(4-8)$, temperature $\left(26-34^{\circ} \mathrm{C}\right)$ and concentration (50 ppm). Thermodynamic studies performed at 27 $37^{\circ} \mathrm{C}$ and concentration at $50 \mathrm{ppm}$.

Determining of phenol adsorbed was calculated using the formula:

$\mathrm{q}_{\mathrm{e}}=\frac{\left(\mathrm{c}_{0}-\mathrm{c}\right) \times \mathrm{v}}{\mathrm{m}}$

The definition of above symbols can be described in the following:

qe $=$ amount of metal absorbed over a certain time $(\mathrm{mg} / \mathrm{g})$

$\mathrm{CO}=$ initial concentration of phenol $(\mathrm{mg} / \mathrm{L})$

$C=$ concentration of fenol after a certain time (mg/L) 
$V=$ volume of phenol solution $(L)$

$\mathrm{m}=$ mass of activated carbon $(\mathrm{g})$

\subsection{Langmuir adsorption isotherm}

Langmuir isotherm is used based on the assumption that maximum adsorption corresponds to a single layer of adsorbate molecules on the surface, where the adsorption energy is constant and no molecules migration on the surface. Linear form of the Langmuir isotherm equation is shown from the following equation:

$\frac{\ln \left(\frac{C_{0}}{C_{A}}\right)}{C_{0}-C_{A}}+k_{0}=\frac{k_{1} \cdot t}{C_{0}-C_{A}}$

were $C A$ is the equilibrium concentration $(\mathrm{mg} / \mathrm{L})$, qe is the amount of substance adsorbed each gram of adsorbent $(\mathrm{mg} / \mathrm{g})$, Qo and $b$ are the Langmuir constants declared in a row that the adsorption capacity and energy of adsorption, respectively (Anshar 2006). on the surface are not ideal, rough and irregular. Effect of concentration on the adsorption according to Freundlich isotherm can be expressed as follows:

$x / m=k . c n$

where, $\mathrm{x} / \mathrm{m}$ is the amount of adsorbate that adsorbed ( $\mathrm{mg}$ adsorbate / gram of adsorbent). Other symbols can be described in the following:

$c=$ concentration of the adsorbate at equilibrium ( $\mathrm{mg} / \mathrm{mL})$

$k=$ constant sorption

$\mathrm{n}=$ parameter affinity

Freundlich isotherm shape of the curve is not linear at low concentrations but still convex to the axis of concentration. This equation is only valid for the adsorbate concentration is low. If the Freundlich equation written in the form of logarithm is obtained a straight line equation as follows:

$\log (x / m)=\log (k . c n)$

$\log (x / m)=\log k+n \log c$

\subsection{Freundlich adsorption isotherm}

Freundlich adsorption isotherm is often use to study the adsorption of the solution

Table 1. General content of rice husk. Adopted from reference (Suharno et al., 1997)

\begin{tabular}{lc}
\hline \multicolumn{1}{c}{ Component } & Percentage (\%) \\
\hline Water content & 9,02 \\
Crude protein & 3,03 \\
lipid & 1,18 \\
Crude fiber & 35,68 \\
Ask & 17,71 \\
Carbohydrate rough & 33,71 \\
\hline Acording DTC-IPB & \\
Carbon & 1,33 \\
Hydrogen & 1,54 \\
Oksigen & 33,64 \\
Silica $\left(\mathrm{SiO}_{2}\right)$ & 16,98 \\
\hline
\end{tabular}


A. M. Anshar, P. Taba, I. Raya. Kinetic and Thermodynamics Studies on the Adsorption... $\mid 51$

\section{RESULTS AND DISCUSSION}

Table 1 shows the analysis of risk husk. This result was in a good agreement with recent references.

To confirm the component involved in the process, we conducted an infrared spectroscopy (FTIR) analysis to the sample (see Figures 1, 2, and 3). Figure $\mathbf{1}$ is the FTIR of rice husk, whereas Figures 2 and 3 are the the FTIR results of samples burned at a temperature of 300 and $400^{\circ} \mathrm{C}$, respectively. Several peaks were detected, confirming the existence of various components in the samples. Based on the Figures, we found that most of the samples contained silica component, in which this result was in a good agreement with the analysis shown in Table 1.
To confirm the component available in the sample, we summarized the FTIR peaks in Table 2 . Table $\mathbf{2}$ shows the several important peaks in the FTIR results shown in Figures 1, 2, and 3. As shown in the table, compared to the current literatures about the functional groups, the FTIR results confirmed that all samples contained SiO and carbon components.

Table 3 shows specific surface area, mean pore, and total pore volume of the samples. We compared the samples using method 1 and 2. Specific surface area, mean pore, and total pore volume of samples depended on the processing condition (i.e. method 1 and 2 ), as well as heating temperature.

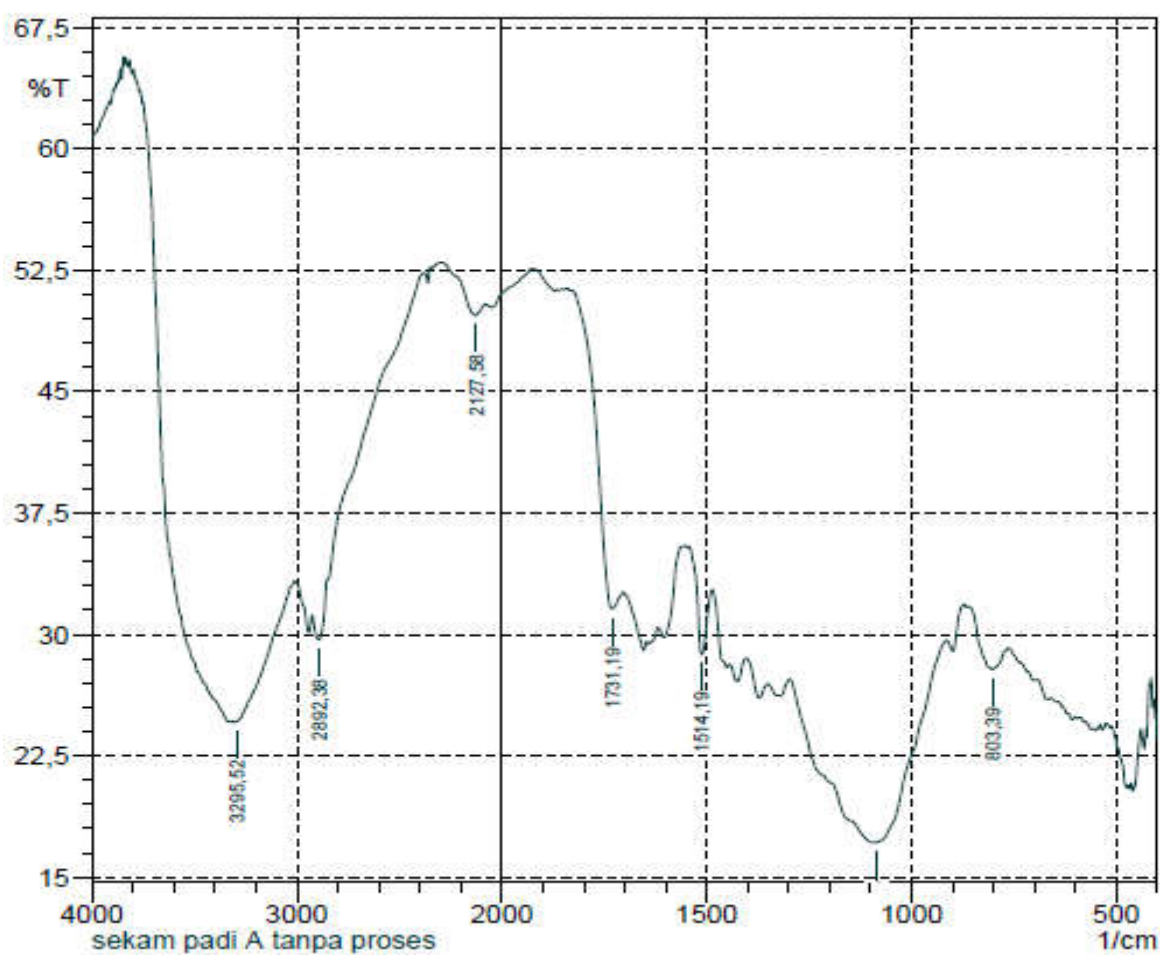

Figure 1. The FTIR of rice husks 
52 | Indonesian Journal of Science \& Technology, Volume i Issue 1, April 2016 Hal 47-6o

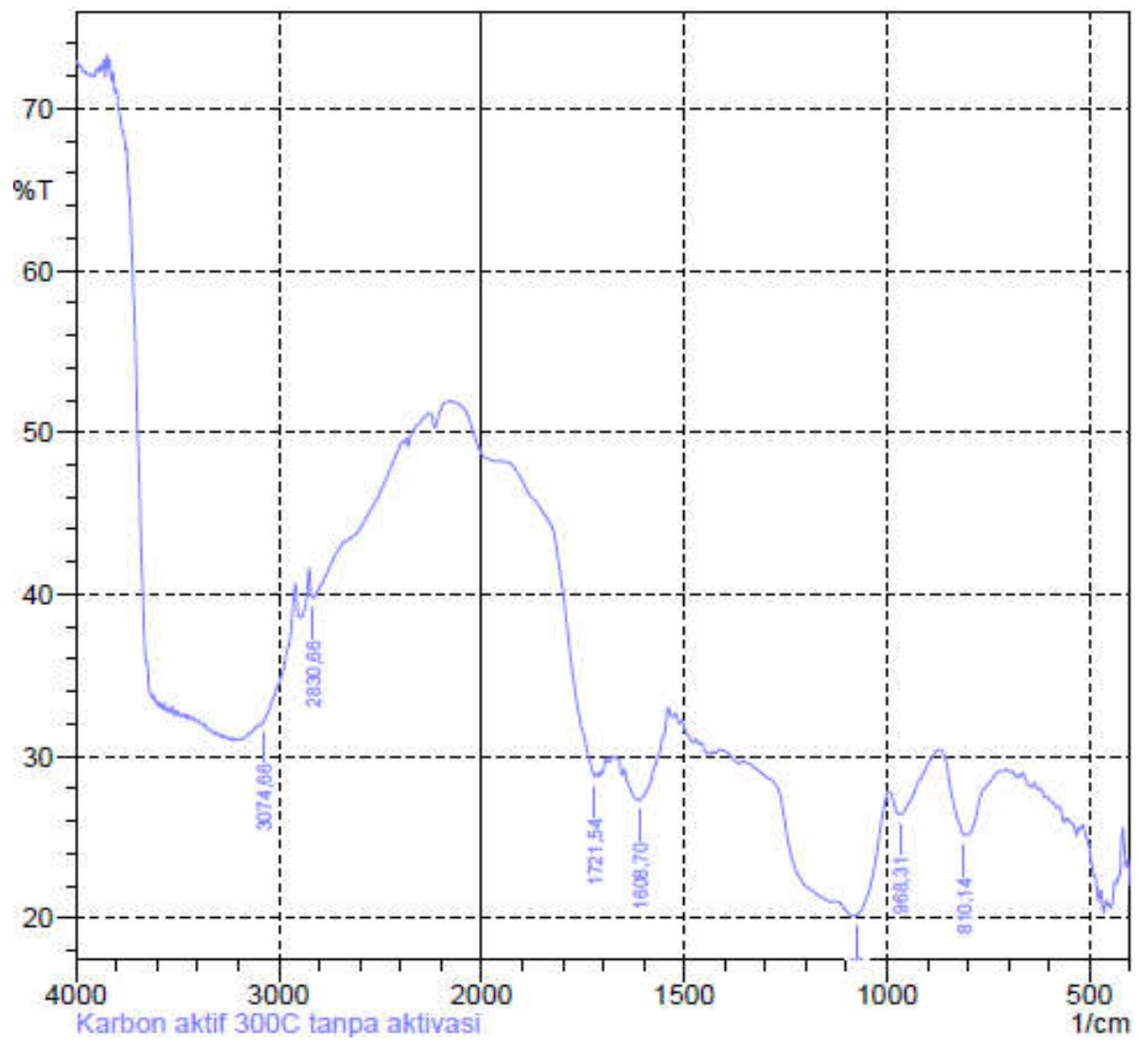

Figure 2. The FTIR spectra of active carbon products burned at a temperature of $300^{\circ} \mathrm{C}$

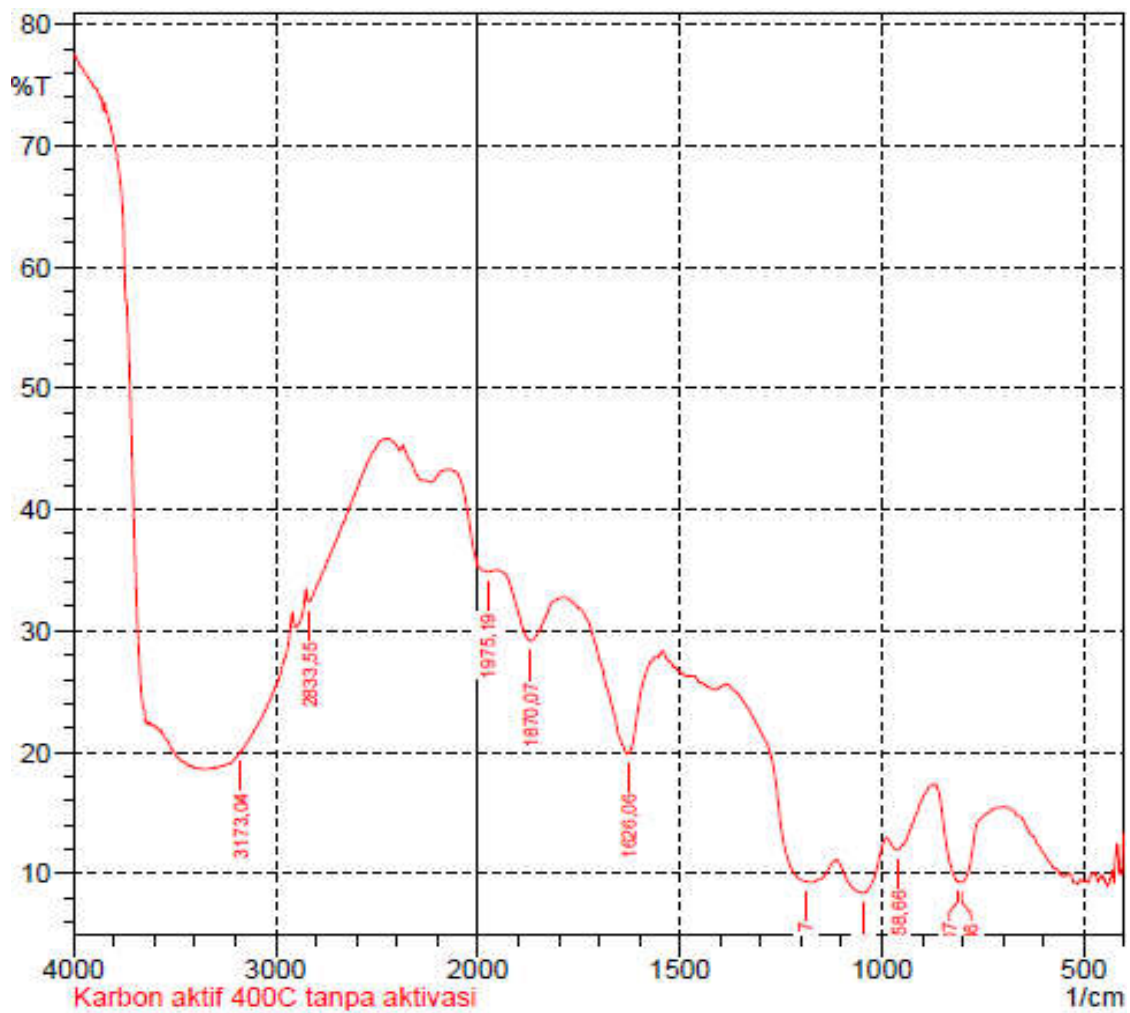

Figure 3. The FTIR spectra of active carbon products burned at a temperature of $400^{\circ} \mathrm{C}$ 
Table 2. Functional groups gained from FTIR analysis from rice husk and active carbon from combustion at temperature 300 and $400^{\circ} \mathrm{C}$

\begin{tabular}{|c|c|c|c|c|c|c|}
\hline \multirow[t]{2}{*}{ No } & \multicolumn{2}{|c|}{ Rice Husk } & \multicolumn{2}{|c|}{$\begin{array}{l}\text { Active carbon } 300^{\circ} \mathrm{C} \\
\text { without activation }\end{array}$} & \multicolumn{2}{|c|}{$\begin{array}{c}\text { Active carbon } 400^{\circ} \mathrm{C} \\
\text { without activation }\end{array}$} \\
\hline & wavelength & $\begin{array}{l}\text { Functional } \\
\text { groups }\end{array}$ & wavelength & $\begin{array}{l}\text { Functional } \\
\text { groups }\end{array}$ & wavelength & $\begin{array}{c}\text { Functional } \\
\text { groups }\end{array}$ \\
\hline 1 & 803,39 & $\mathrm{SiO}$ & 810,14 & $\mathrm{SiO}$ & 810,46 & $\mathrm{SiO}$ \\
\hline 2 & 1086,93 & $\mathrm{SiO}$ & 968,31 & $\mathrm{SiO}$ & 812,01 & $\mathrm{SiO}$ \\
\hline 3 & 1514,19 & $\begin{array}{r}\mathrm{CH} \text { from } \\
\mathrm{CH}_{2} \text { and } \\
\mathrm{CH}_{3}\end{array}$ & 1075,36 & $\mathrm{SiO}$ & 958,66 & $\mathrm{SiO}$ \\
\hline 4 & 1731,19 & $C=O$ & 1608,7 & $C=C$ & 1046,43 & $\mathrm{SiO}$ \\
\hline 5 & 2892,38 & $\begin{array}{r}\mathrm{C}-\mathrm{H} \\
\text { alifatic }\end{array}$ & 1721,54 & $C=0$ & 1189,17 & $\mathrm{SiO}$ \\
\hline 6 & 3295,52 & $\mathrm{OH}$ & 3074,66 & $\mathrm{SiOH}$ & 1626,06 & $C=C$ \\
\hline 7 & & & & & 1870,07 & $C=O$ \\
\hline
\end{tabular}

Table 3. Specific surface area, mean pore and total pore volume of active carbon products of combustion from rice husk at a temperature 300 and $400^{\circ} \mathrm{C}$.

\begin{tabular}{|c|c|c|c|c|}
\hline No & Sample & $\begin{array}{c}\text { Specific surface } \\
\text { area } \\
\left(\mathrm{m}^{2} / \mathrm{g}\right)\end{array}$ & $\begin{array}{c}\text { mean pore } \\
(\AA ̊)\end{array}$ & $\begin{array}{l}\text { total pore } \\
\text { volume } \\
\text { (cc/g) }\end{array}$ \\
\hline 1 & $\begin{array}{l}\text { Active carbon } 300 \\
\text { with out activation }\end{array}$ & 38,248 & $1,735 E+01$ & $3,318 \mathrm{E}-02$ \\
\hline 2 & $\begin{array}{l}\text { Active carbon } 300 \\
\text { with method } 1 \\
\text { activation }\end{array}$ & 115,282 & $1,821 E+01$ & $1,050 \mathrm{E}-01$ \\
\hline 3 & $\begin{array}{l}\text { Active carbon } 300 \\
\text { with method } 2 \\
\text { activation }\end{array}$ & 105,366 & $1,578 \mathrm{E}+01$ & $8,311 \mathrm{E}-02$ \\
\hline 4 & $\begin{array}{l}\text { Active carbon } 400 \\
\text { with out activation }\end{array}$ & 55,074 & $8,040 E+01$ & $2,214 \mathrm{E}-01$ \\
\hline 5 & $\begin{array}{l}\text { Active carbon } 400 \\
\text { with method } 1 \\
\text { activation }\end{array}$ & 284,963 & $3,278 \mathrm{E}+01$ & 4,670E-01 \\
\hline 6 & $\begin{array}{l}\text { Active carbon } 400 \\
\text { with method } 2 \\
\text { activation }\end{array}$ & 64,815 & $7,110 \mathrm{E}+01$ & $2,304 \mathrm{E}-01$ \\
\hline
\end{tabular}


The X-ray diffraction obtained results from active carbon shown that the amorphous rate of active carbon combustion at a temperature $400^{\circ} \mathrm{C}$ and then activated using method 2 most lower if compared with other activated carbon as in Figure 4.

For the analysis results using the (SEM), in Figure 5 the shape of the surface of activated carbon is different between one and the other. This is due to differences in the way the preparation to prepare carbon. Figure 5 showed the difference between activated carbon products of combustion at a temperature of $300^{\circ} \mathrm{C}$ undergo activation method 1 with activated carbon at a temperature of $400^{\circ} \mathrm{C}$ combustion products that undergo activation method 1.

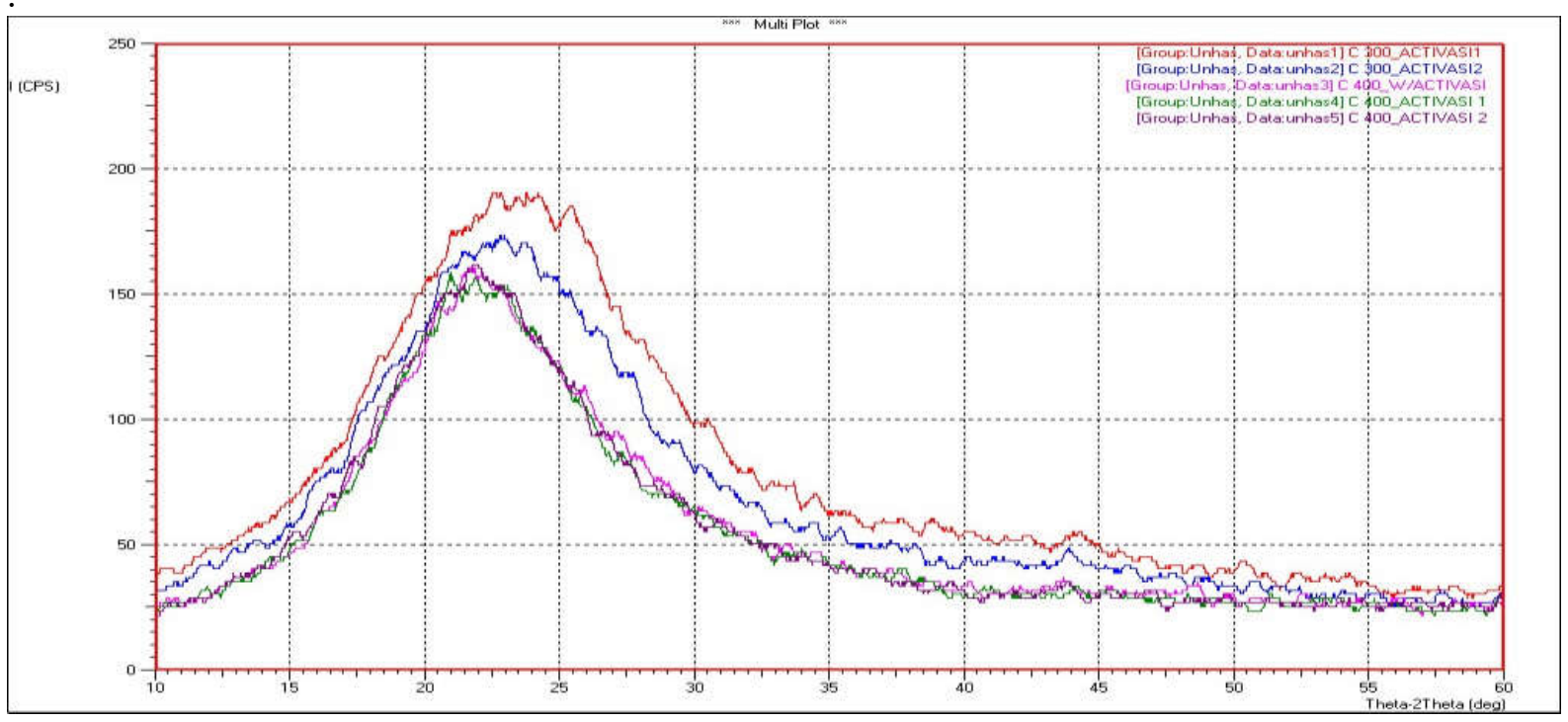

Figure 4. The XRD spectra of active carbon products from combustion in each method

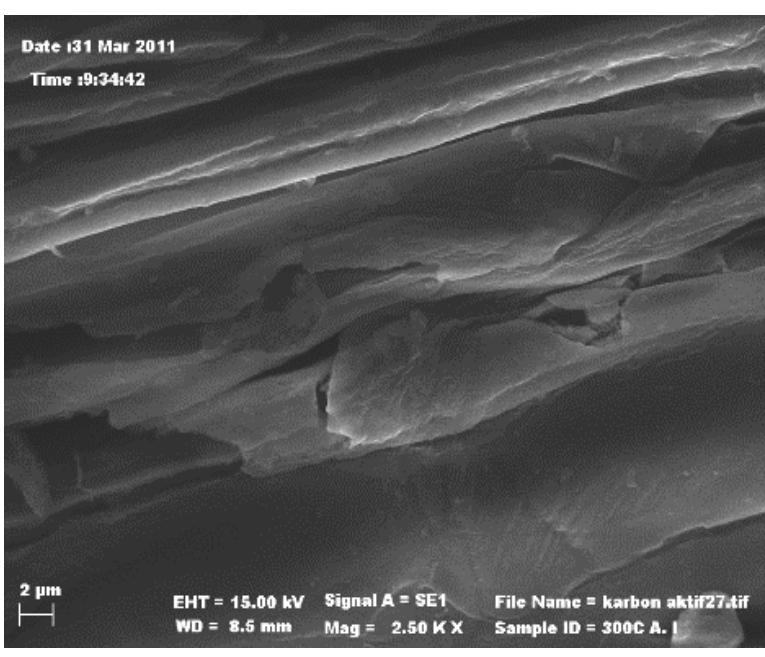

(a)

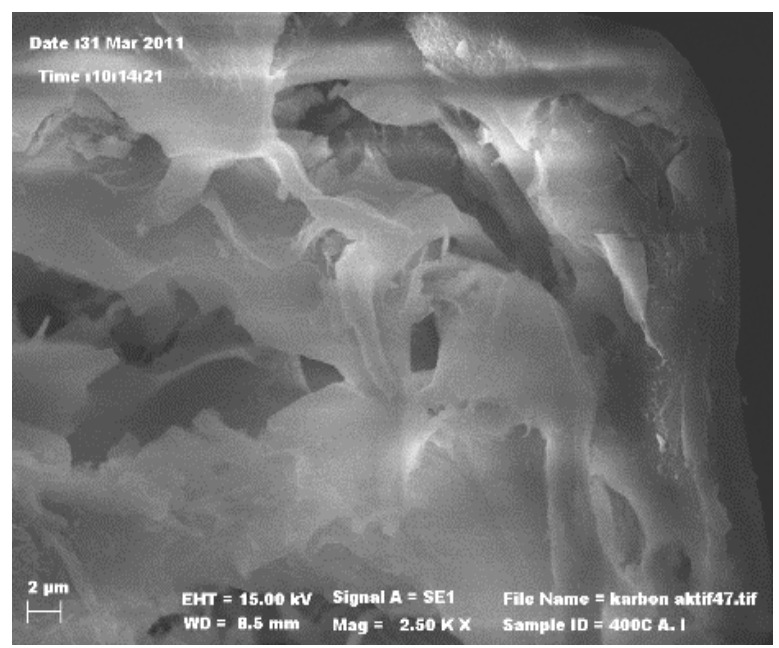

(b)

Figure 5. The SEM results of activated carbon products of rice husk combustion at a temperature of $300^{\circ} \mathrm{C}$ experiencing activation method 1 (a) and a temperature of $400^{\circ} \mathrm{C}$ were experiencing activation method 1 (b) $2,500 \mathrm{x}$ 
Figure 6 shows relationship of interaction time with the amount of adsorbed phenol on active carbon and the activated carbon. For optimum interaction conditions, the interaction can be done in the optimum interaction time between phenol and active carbon. Activated carbon that was produced by combustion at a temperature $300{ }^{\circ} \mathrm{C}$ and $400{ }^{\circ} \mathrm{C}$ using Method 1 or Method 2 are excellent. Activated carbon by embusmentat $400^{\circ} \mathrm{C}$ was the most widely to adsorbed phenol the optimum adsorption time was 45 minutes for $1.052 \mathrm{mg} / \mathrm{g}$ adsorbent. Or, we can conclude that the sample can adsorb about $21.067 \mathrm{ppm}$.
Figure 7 shows the relationship of $\mathrm{pH}$ condition and the adsorbed phenol amount on the active carbon and the activated carbon. The result showed that $\mathrm{pH}$ played an important role for gaining optimum adsorption process. Indeed, different samples can adsorb different abilities to adsorb phenol. From the figure, specifically sample produced by burning rice husk at a temperature of $400^{\circ} \mathrm{C}$, activation method 1 was the best compared with other samples. The best $\mathrm{pH}$ condition for this sample was at a $\mathrm{pH}=5$. The best sample provided the adsorption of phenol of $0.453 \mathrm{mg} / \mathrm{g}$ adsorbent.

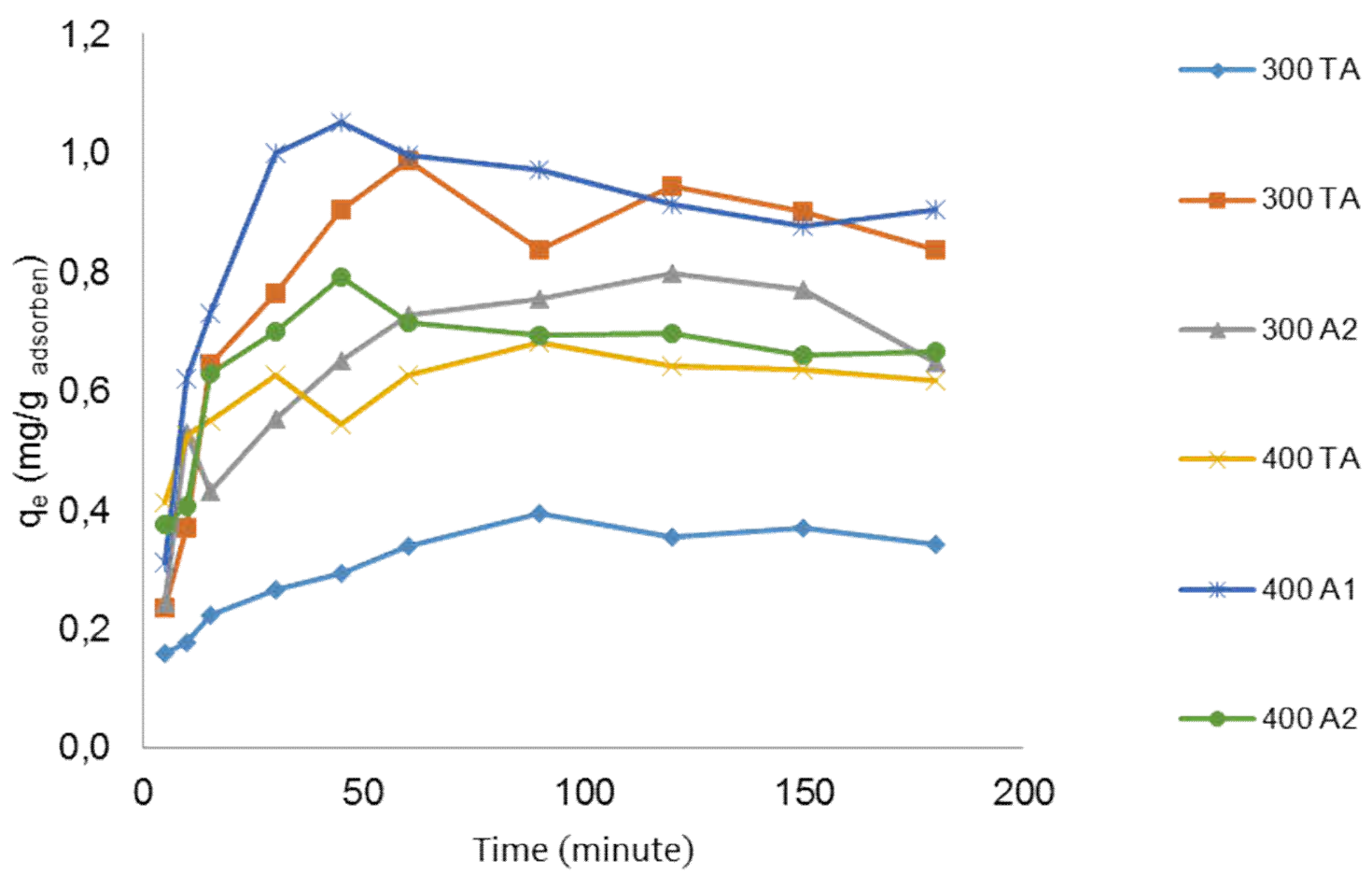

Figure 6. Relationship of interaction time with the amount of adsorbed phenol on active carbon and the activated carbon 


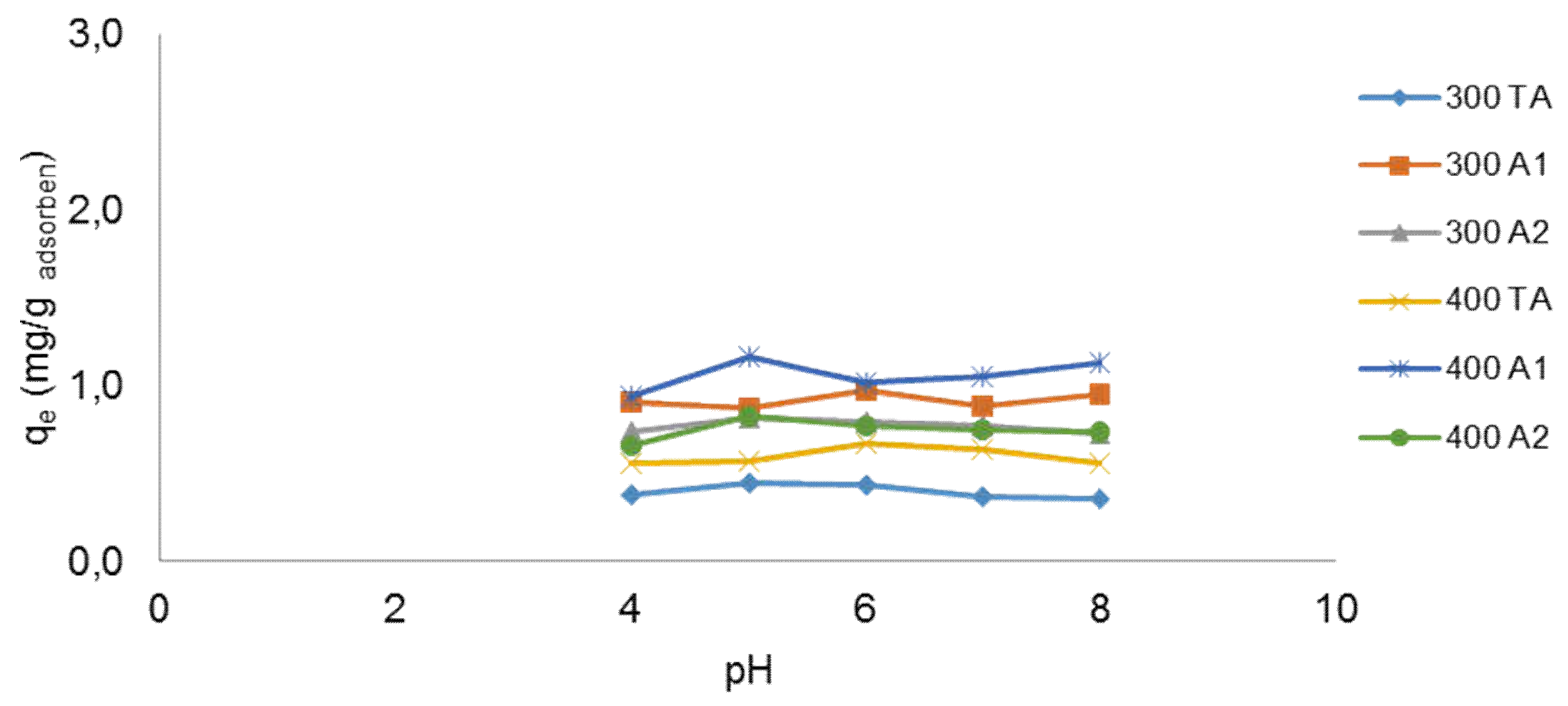

Figure 7. Relationship of $\mathrm{pH}$ and the adsorbed phenol amount on active carbon and the activated carbon

Figure 8 shows graph of effect of concentration of phenol on the possible interaction of phenol with activated carbo. We used various rice husk sample burned with various temperatures and activation methods. The result showed that by varying concentrations, the adsorbed phenol can be controlled. The more amount of adsorbed phenol resulted in the more possibility for phenol to be adsorbed. From the figure, we can obtained that the best sample was rice husk burned at a temperature of $400{ }^{\circ} \mathrm{C}$ and activated using method 1 .

Table 4 shows adsorption capacity, adsorption intensity and the change in Gibbs free energy of active carbon products from rice husk combustion at a temperature 300 and $400^{\circ} \mathrm{C}$ that were not activated using method 1 and method 2. From the data, we calculated the amount of adsorption capacity, the intensity of adsorption based on isothermal Langmuir and the change of Gibbs free energy which uses Langmuir Hinshelwood equations kinetics model for activated carbon from burning rice husk at
300 and $400^{\circ} \mathrm{C}$ that were not activated as well experienced by activation method 1 and method 2.

Table 5 shows adsorption capacity, adsorption intensity on activated carbon from burned of rice husk at a temperature $300^{\circ} \mathrm{C}$ and $400^{\circ} \mathrm{C}$ that were not activated and experiencing activation method 1 and method 2. The adsorption capacity and intensity of adsorption was calculated based on the Freundlich isotherm.

Figure 9 shows effect of temperature variation on the adsorption of phenol that conducted using activated carbon from rice husk burning at temperature $300^{\circ} \mathrm{C}$ and $400^{\circ} \mathrm{C}$ without experiencing activation, activated using method 1 and 2 . The process was conducted in the optimum contact time and $\mathrm{pH}$ for each activated carbon. The result showed that the higher temperature resulted in the more phenol to be adsorbed.The temperature range used was from 27 to $37^{\circ} \mathrm{C}$. 
A. M. Anshar, P. Taba, I. Raya. Kinetic and Thermodynamics Studies on the Adsorption... $\mid 57$

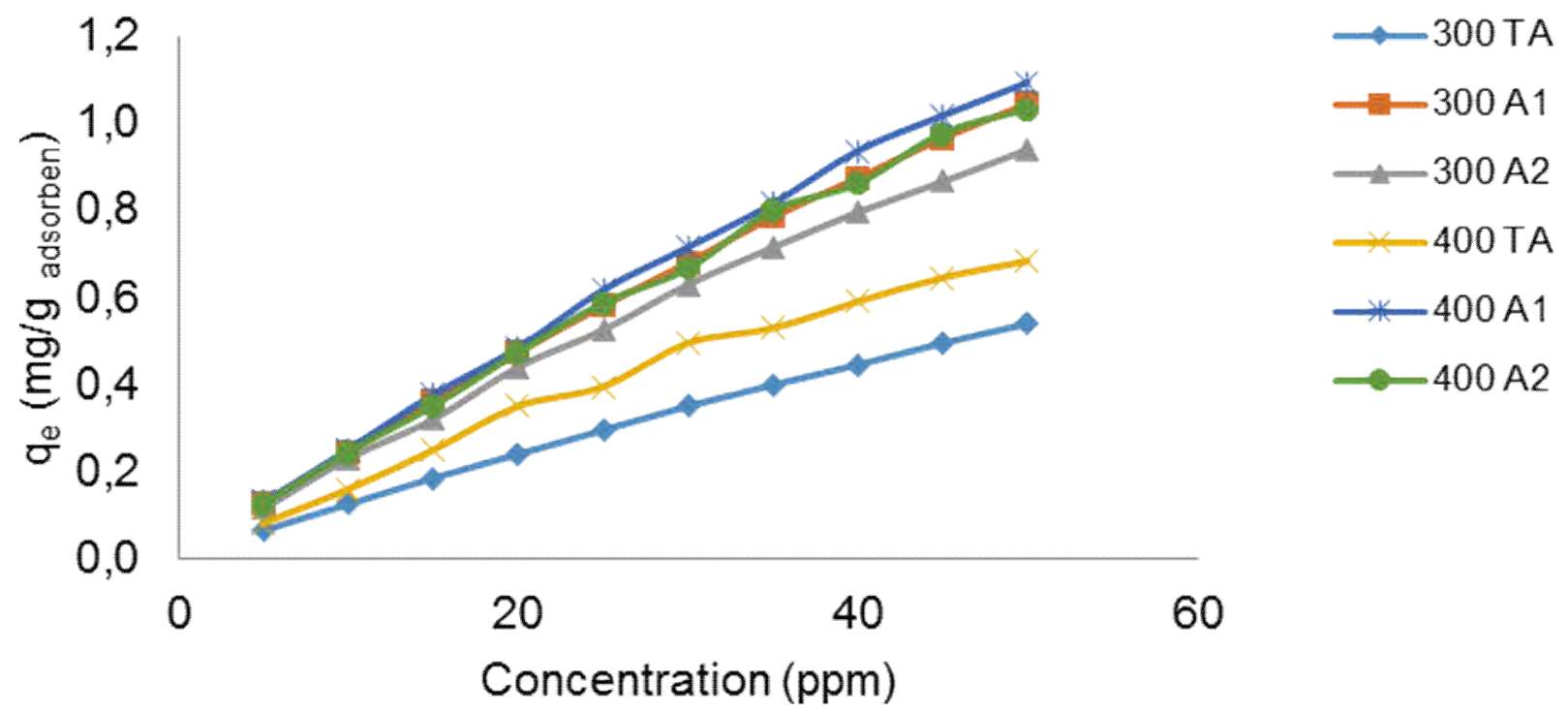

Figure 8. Graph of concentration variation from phenol that interaction with activated carbon rice husk combustion

Table 4. Adsorption capacity, adsorption intensity and the change in Gibbs free enegy of active carbon products from rice husk combustion at a temperature 300 and $400^{\circ} \mathrm{C}$ waren't activated and ware experiencing activation method 1 and method 2

\begin{tabular}{lcccccc}
\hline & 300 TA & 300 A1 & 300 A2 & 400 TA & 400 A1 & 400 A2 \\
\hline $\begin{array}{l}\text { Adsorption } \\
\text { capasity } \\
\text { (mg/g } \\
\text { adsorben) }\end{array}$ & 2,3696 & 3,6101 & 3,0487 & 2,6041 & 3,9370 & 3,4013 \\
$\begin{array}{l}\text { Adsorption } \\
\text { Intensity } \\
\text { (L/mg) }\end{array}$ & 0,00749 & 0,01419 & 0,01444 & 0,01043 & 0,01408 & 0,01526 \\
$\begin{array}{l}\text { The change of } \\
\text { Gibbs free } \\
\text { enegi (KJ/mol) }\end{array}$ & $-23,829$ & $-25,430$ & $-25,323$ & $-24,654$ & $-25,493$ & $-25,440$ \\
$\begin{array}{l}\text { Adsorption } \\
\text { type }\end{array}$ & physic & physic & Physic & physic & physic & physic \\
\hline
\end{tabular}


Table 5. Adsorption capacity, adsorption intensity on activated carbon from burned of rice husk at a temperature 300 and $400^{\circ} \mathrm{C}$ weren't activated and are experiencing activation method 1 and method 2

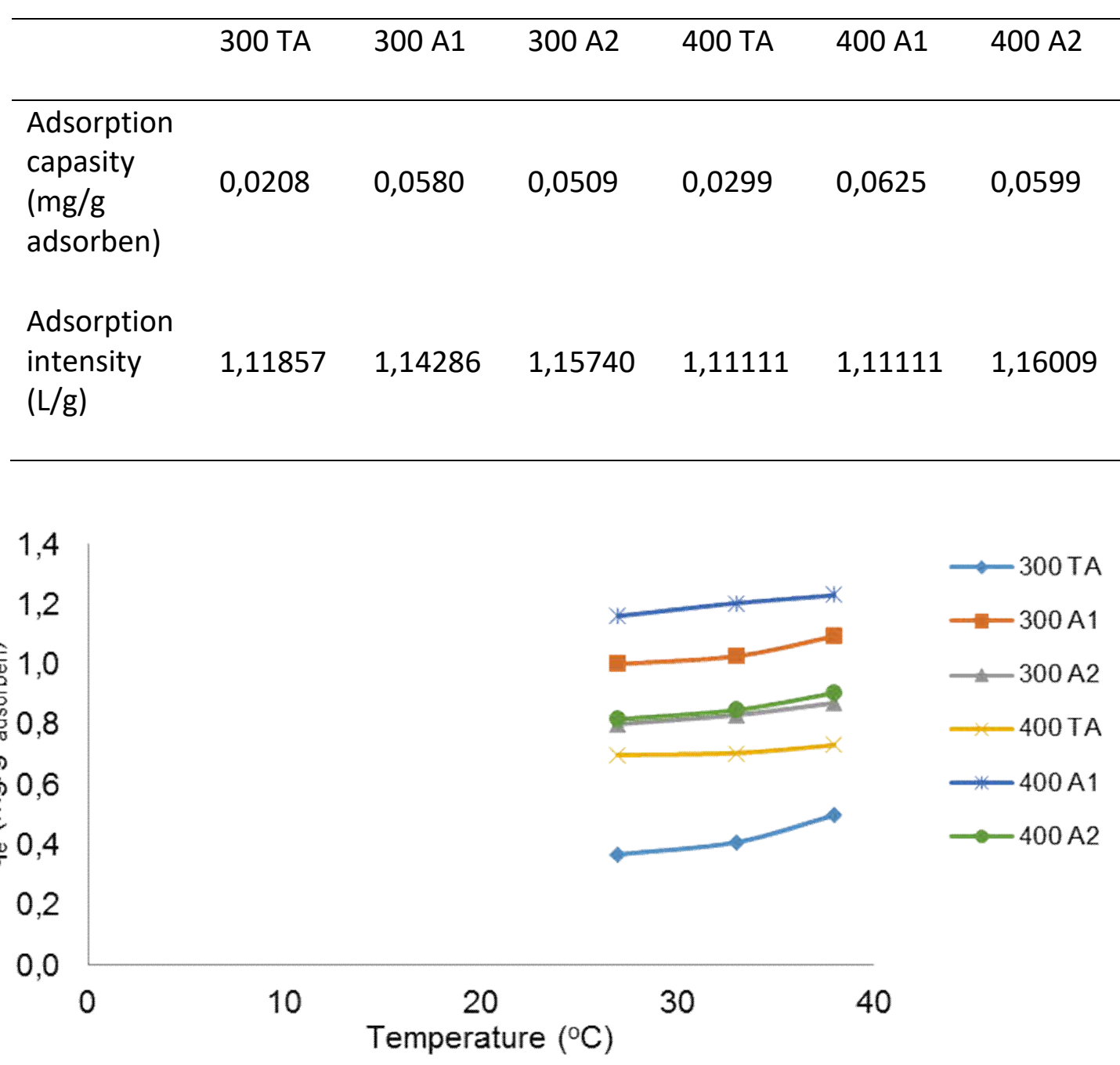

Figure 9. Graph of temperature variation from phenol thet interacted with activated carbon from rice husk burning at temperature 300 and $400^{\circ} \mathrm{C}$ who have not experienced activation, activated with method 1 and activated with the method 2 on optimum contact time and $\mathrm{pH}$ for each activated carbon.

\section{CONCLUSIONS}

Based on the experimental results, we can conclude that:

1. The best activated carbon used for adsorbing phenol was obtained for activated carbon derived from rice husk combustion at temperature of $400^{\circ} \mathrm{C}$ experiencing activation method 1 with a contact time of 45 minutes at $\mathrm{pH} 5$ and the solution temperature of about $37^{\circ} \mathrm{C}$. This is because this carbon is able to adsorb $1.231 \mathrm{mg}$ phenol for each gram adsorbent.

2. Based on the Langmuir isotherm equation, the adsorption capacity was $3.9370 \mathrm{mg} / \mathrm{g}$ adsorbent, whereas based in Freundlich isotherm equation the 
capacity of activated carbon was 0.0625 $\mathrm{mg} / \mathrm{g}$ of adsorbent.

3. Functional group that involved in this study was $-\mathrm{SiOH}$ group, $\mathrm{C}=\mathrm{C}, \mathrm{C}=\mathrm{O}$ and SiO group.

\section{AUTHOR'S NOTES}

The author(s) declare(s) that there is no conflict of interest regarding the publication of this article. Authors confirmed that the data and the paper are free of plagiarism.

\section{REFERENCES}

Abdullah, A. H., Kassim, A., Zainal, Z., Hussien, M. Z., Kuang, D., Ahmad, F., and Wooi, O. S. (2001). Preparation and characterization of activated carbon from gelam wood bark (Melaleuca cajuputi). Malaysian journal of analytical sciences, 7(1), 65-68.

Anshar, A. M., (2006). Study of methylene blue and eosin in adsorption Humin, (Master thesis, Universitas Gajah Mada).

Anwar, B., Rosyid, N. H., Effendi, D. B., Nandiyanto, A. B. D., Mudzakir, A., and Hidayat, T. (2016). Isolation of bacterial cellulose nanocrystalline from pineapple peel waste: Optimization of acid concentration in the hydrolysis method. In Proceedings of International Seminar On Mathematics, Science, And Computer Science Education (MSCEIS 2015) (Vol. 1708, p. 040001). AIP Publishing.

Danarto, Y.C., and Samun, T. (2008). The Effect of carbon activation from rice husk on $\mathrm{Cr}(\mathrm{VI})$ adsorption process, Ekuilibrium, 7(1), 13-16.

Edwin, W., (2005). Utilization of shell walnuts activated carbon as 4-chlorophenol adsorbent in water (Master thesis, Universitas Hasanudin).

Elias, M. S., Zainal, Z., Hussein, Z. M., Taufik-Yap, Y. H., 2001, Removal of phenol dissolved in water through photodegradation using titanium dioxide (TiO2), Malaysian journal of analytical sciences, 7(1), 1-6.

Estevinho, B. N., Martins, I., Ratola, N., Alves, A., and Santos, L., (2007). Removal of 2,4dichlorophenol and pentachlorophenol from waters by sorption using coal fly ash from a Portuguese thermal power plant, Journal of hazardous materials, 143, 535540.

Estevinho, B. N., Ratola, N., Alves, A., and Santos, L. (2006). Pentachlorophenol removal from aqueous matrices by sorption with almond shell residues. Journal of hazardous materials, 137(2), 1175-1181.

Kalderis, D., Koutoulakis, D., Paraskeva, P., Diamadopoulos, E., Otal, E., del Valle, J. O., and Fernandez-Pereira, C. (2008). Adsorption of polluting substances on activated carbons prepared from rice husk and sugarcane bagasse. Chemical engineering journal, 144(1), 42-50.

Kermani, M., Pourmoghaddas, H., Bina, B., and Khazaei, Z. (2006). Removal of phenol from aqueous solutions by rice husk ash and activated carbon. Pakistan journal of biological science, 9, 1905-1910. 
60 | Indonesian Journal of Science \& Technology, Volume 1 Issue 1, April 2016 Hal 47-6o

Mortland, M. M., Shaobai, S., and Boyd, S. A. (1986). Clay-organic complexes as adsorbents for phenol and clorophenols, Clays and clay minerals, 34(5), 581-585.

Qadeera, R., and Rehan, A. H. (2002). Study of the adsorption of phenol by activated carbon from aqueous solutions, Turkish journal of chemistry, 26, 357 - 361.

Rahman, T., Fadhlulloh, M. A., Nandiyanto, A. B. D., and Mudzakir, A. (2015). Review: Sintesis karbon nanopartikel. Jurnal integrasi proses, 5(3), 120-131.

Rahmi (2007). Adsorption of phenol in cross binds chitosan composite membrane, Rekayasa kimia dan lingkungan journal, 6(1), 28-34.

Sembodo, B. S. T. (2005). Adsorption equilibrium isotherms of lead in rice husk ash, Ekuilibrium journal, 4(2), 100 - 105.

Tarigan, Z., Edward, and Rozak, A. (2003). The heavy metals content of $\mathrm{Pb}, \mathrm{Cd}, \mathrm{Cu}, \mathrm{Zn}$ and $\mathrm{Ni}$ in Membramo sea water and river sediments in Papua and the relation with the interests of aquaculture, Makara Sains, 7(3), 1-10.

Ubago-Perez, R., Carrasco-Marín, F., Fairén-Jiménez, D., and Moreno-Castilla, C. (2006). Granular and monolithic activated carbons from $\mathrm{KOH}$-activation of olive stones. Microporous and mesoporous materials, 92(1), 64-70.

Wahjuni, N. S., Anggara, D., and Rinjayanti, D. (2005). Comparison of adsorption level from chitin and activated carbon to absorb the chromium in stirred tank, Ekuilibrium, 4(2), 1-10.

Watari, T., Nakata, A., Kiba, Y., Torikai, T., and Yada, M., 2005, Fabrication of porous SiO2/C composite from rice husk, Journal of european ceramic society, 26, 797-801.

Yapar, S., Klahre, P., and Klummp, P. (2004). Hydrotalcite as a potential sorbent for the removal of 2,4-dichlorophenol, Turkish journal of engineering enviromental science, $28,41-48$. 